\title{
DISEMINASI AKAD DAN PRODUK BANK SYARIAH PADA MASYARAKAT GAMPONG KEUDE KECAMATAN PEUDAWA ACEH TIMUR
}

\author{
Suryani \\ IAIN Lhokseumawe \\ suryapijar@yahoo.com
}

\begin{abstract}
The purpose of this community service program is to increase an integrated and integrated understanding with the community and community leaders of Gampong Keude, Peudawa District, East Aceh, regarding products and products in Islamic banking. Sharia banking product and product dissemination activities in the community need to be given to the speakers to gain insight into the Gampong Keude community about sharia banks. This activity results are the community, and Gampong Keude community leaders know Islamic banking contracts and products. They are interested in joining Islamic banking in and around East Aceh.
\end{abstract}

Keywords: Dissemination, Contracts, Products, Islamic Banks, Community Service, Gampong Keude.

\begin{abstract}
Abstrak
Tujuan program pengabdian masyarakat ini adalah untuk meningkatkan pemahaman yang komprehensif dan integratif kepada masyarakat dan tokoh masyarakat Gampong Keude Kecamatan Peudawa Aceh Timur mengenai akad dan produk dalam perbankan syariah. Kegiatan diseminasi akad dan produk perbankan syariah di tengah masyarakat perlu diberikan oleh pemateri untuk membuka wawasan masyarakat Gampong Keude tentang bank syariah. Hasil dari kegiatan ini adalah masyarakat, dan tokoh masyarakat Gampong Keude memiliki pengetahuan tentang akad dan produk perbankan syariah dan memiliki keinginan untuk bergabung menjadi nasabah perbankan syariah yang ada di sekitar kota Aceh Timur.
\end{abstract}

Kata kunci: Diseminasi, Akad, Produk, Bank Syariah, Pengabdian Masyarakat, Gampong Keude.

\section{PENDAHULUAN}

Indonesia merupakan negara majemuk dengan banyaknya perbedaan agama dan suku. Begitupun juga dengan sistem pemerintahan daerah di masing-masing wilayah provinsi Negara Kesatuan Republik Indonesia (NKRI). Provinsi Nanggroe Aceh Darussalam merupakan provinsi yang menonjolkan sistem pemerintahan daerah dengan berprinsip pada syariat Islam, hal ini menjadi perbedaan Aceh dengan beberapa provinsi Indonesia lainnya. terdapat salah satu provinsi yang menonjolkan sistem pemerintahan daerah yang berbeda yaitu Provinsi Nanggroe Aceh Darussalam. Sebagai salah satu provinsi di Indonesia, Aceh diberi status sebagai daerah istimewa dan juga diberi kewenangan otonomi khusus.

Sebagai daerah yang diberi kewenangan otonomi khusus, pembagian dan pelaksanaan yang berkaitan dengan pemerintah Aceh dan 
kabupaten yang berhubungan dengan syariat Islam diatur dengan sebutan Qanun Aceh.

Qanun ialah peraturan perundang-undangan sejenis peraturan daerah yang mengatur penyelenggaraan pemerintah dan kehidupan masyarakat di provinsi Aceh. Salah satu yang masuk dalam peraturan Qanun Aceh yaitu tentang Lembaga Keuangan Syariah No. 11 Tahun 2018.

Peraturan mengenai kegiatan lembaga keuangan dalam rangka mewujudkan ekonomi masyarakat Acel yang adil sejahtera dalam naungan syariat islam terdapat dalam Qanun Aceh nomor 11 tahun 2018. Dasar yang melandasi terbitnya Qanun tersebut merupakan tindak lanjut dari Qanun Aceh No. 8 Tahun 2014 mengenai pokok-pokok syariat Islam yang secara tegas telah mewajibkan bahwa lembaga keuangan yang beroperasi di Aceh wajib dilaksanakan berdasarkan prinsip syariah. Qanun Aceh No. 11 tahun 2018 sudah di berlakukan sejak tanggal 4 Januari 2019.

Peraturan Qanun ini diberlakukan kepada lima kelompok yaitu 1) setiap orang beragama islam yang bertempat tinggal di Aceh atau Badan Hukum yang melakukan transaksi keuangan di Aceh, 2) setiap orang yang beragama bukan islam, Badan Usaha/Badan Hukum yang melakukan transaksi keuangan dengan pemerintah Aceh dan Kabupaten/Kota, 3) Setiap Orang yang beragama Islam melakukan transaksi di Aceh, 4) LKS yang menjalankan usaha di Aceh serta, 5) LKS di luar Aceh yang berkantor pusat di Aceh. Adapun yang di maksud Lembaga Keuangan Syariah ialah Bank Syariah, Lembaga Keuangan NonBank, dan Lembaga Keuangan lainnya.

Berangkat dari fenomena sistem peraturan Qanun di Aceh mengenai Lembaga Keuangan Syariah tentunya menjadi fenomena yang menarik akademisi maupun praktisi. Mengingat, perbankan Islam atau perbankan syariah merupakan fenomena baru dalam dunia Ekonomi modern, kemunculan perbankan Islam seiring dengan upaya gencar yang dilakukan oleh para pakar Islam yang diyakini akan mampu mengganti dan memperbaiki sistem ekonomi konvensional yang berbasis pada bunga.

Bank Islam atau bank syariah ialah suatu sistem perbankan yang dikembangkan berdasarkan syariah (hukum) Islam. Bank syariah di Indonesia terhitung masih sangat muda, begitupun dengan perkembangannya yang lambat. Hal tersebut dapat di buktikan dengan pertumbuhan aset perbankan syariah pada tahun 2009 sampai 2010 selalu berada diatas 30\%, sedangkan pada tahun 2013 mengalami penurunan hanya sebesar 24,23\%, sehingga CAGR (Compound Annual Growth Rate) perbankan syari' ah hanya di atas 30\% yang berarti 2 kali lipat dibadningkan pertumbuhan perbankannasional, dengan pangsa pasar (market share) yang masih kecil hanya sebesar 4,70\% dari perbankan nasional (Siregar, 2013).

Meskipun perkembangannya masih terbilang lamban, perkembangan keuangan syariah telah memberikan kontribusi bagi pemenuhan kebutuhan keuangan masyarakat dan juga bagi pembangunan ekonomi nasional. Hal ini ditunjukkan dengan semakin banyaknya produk dan layanan dan berkembangnya infrastruktur yang mendukung industri keuangan syariah di Indonesia (Suwarsi \& Wulandari, 2017) Selain itu Persaingan di dunia perbankan semakin ketat, hal tersebut merupakan tantangan yang harus dihadapi oleh perbankan syariah khususnya di Indonesia. Perbankan syariah nasional diharapkan mempunyai daya saing guna 
menghadapi persaingan global terutama untuk tetap bertahan serta beradaptasi dalam lingkungan bisnis global yang akan dihadapi yaitu Masyarakat Ekonomi ASEAN (MEA).

Strategi pertahanan merupakan langkah yang paling tepat untuk menghadapi era MEA dan untuk itu diseminasi merupakan kunci utama untuk membentuk pertahanan perbankan syariah nasional yang solid untuk mengantisipasi ekspansi perbankan asing ke dalam negeri. Harapan agar masyarakat dapat meninggalkan praktik riba dalam perbankan harus didukung dengan peranan bank syariah untuk aktif melakukan diseminasi dan edukasi kepada masyarakat agar terbangun pemahaman mengenai kemanfaatan produk dan jasa perbankan syariah (Hidayah \& Kartini, 2017).

Sampai saat ini sosialiasi perbankan syari'ah masih belum begitu efektif karena diseminasi terfokus pada Islamisasi, yaitu pengadopsian prinsipprinsip Islam ke dalam sistem perbankan, diseminasi yang dilakukan belum mencapai tahap saintifikasi sehingga diseminasi perbankan syariah menjadi kurang efektif. Kurang efektifnya diseminasi tersebut disebabkan kurangnya upaya dalam rangka diseminasi unsur-unsur Islam agar dapat diterima oleh masyarakat secara umum dan rasional, sehingga perbankan syariah tidak hanya diakui keunggulannya di kalangan loyalis syariah namun juga dapat lebih memasyarakat. Data membuktikan, bahwa market share dari perbankan syariah tidak lebih dari $5 \%$ dari total market share perbankan secara umum (Erfanto, 2016). Bertenggernya market share perbankan syariah sejak belasan tahun di atas satu koma, karena program diseminasi yang dilakukan masih sangat minim (belum optimal) dan belum tepat. Dengan peningkatan efektivitas diseminasi perbankan syariah akan memiliki daya saing yang tinggi di dalam negeri sebagai modal untuk bertahan dan menghadapi persaingan di era MEA, mengingat sebagai negara dengan penduduk Muslim terbesar, sudah selayaknya Indonesia menjadi pelopor dan kiblat pengembangan keuangan syariah di dunia (Alamsyah, 2012).

Peningkatan efektivitas diseminasi perbankan syariah sangatlah penting, untuk itu di perlukan usahausaha yang nyata. Untuk mencapai suatu tujuan yang di inginkan perlu dilakukan perbaikan-perbaikan dalam men mendiseminasikan perbankan syariah di masyarakat, hal tersebut dapat dilihat dari faktor-faktor apa saja yang menjadi masalah dalam meningkatkan efektivitas diseminasi perbankan syariah dimasyarakat khususnya di masyarakat. Masih banyak orang awam yang beranggapan bahwa menabung di bank syariah sama saja dengan dengan menabung di bank konvensional (Kusnandar, 2018). Persepsi umum ini masih menghinggapi masyarakat, sehingga tidak heran mereka masih enggan untuk menjadi nasabah dan mendapatkan pembiayaan dari perbankan syariah. Selain itu peran ulama, ustadz dan da'i masih relatif kecil (Syarif, 2012), hal ini bisa dilihat dari lambannya pertumbuhan perbankan syariah, kendati potensinya sangat besar mengingat populasi penduduk Indonesia beragama Islam.

Masyarakat luas di berbagai segmen masih belum banyak mengerti sistem, konsep, filosofi, produk, keuntungan dan keunggulan bank syariah. Setidaknya ada dua masalah penting dalam perbankan syariah dan dipersepsikan salah oleh masyarakat awam. Pertama, mengenai benchmark pembiayaan dan bagi hasil dengan 
tingkat suku bunga (interest rate) yang berlaku umum di Indonesia misalnya BI rate atau LIBOR di level internasional (Supriyanto, 2015). Masalah Kedua adalah pembiayaan pada perbankan syariah yang dipersepsikan hanya menganut prinsip bagi hasil (Faozan Amar \& Edi Setiawan, 2017).

Oleh karena itu berdasarkan permasalahan di atas, agar perbankan syariah perkembangannya semakin pesat, dosen dan mahasiswa melakukan diseminasi melalui pengabdian masyarakat di Aceh khususnya di wilayah Gampong. Gampong merupakan salah satu pembagian wilayah administratif di Provinsi Aceh. Diseminasi ini bertujuan agar masyarakat Gampong, Aceh mengetahui dengan jelas mengenai perbankan syariah, dan juga mengenai peraturan Qanun tentang Lembaga Keuangan Syariah. Kegiatan diseminasi yang dilakukan diharapkan dapat membuat masyarakat Gampong Keude memiliki pengetahuan yang jelas mengenai akad dan produk perbankan syariah.

\section{METODE PELAKSANAAN}

\section{Metode pendekatan kegiatan yang diguanakan dalam program kegiatan pengabdian masyarakat ini dilaksanakan dalam tiga tahap, yaitu:}

\section{Penyuluhan}

Penyuluhan merupakan cara yang paling tepat dalam memberikan pengetahuan melalui pembagian brosur beberapa bank syariah seperti brosur produk BNI Syariah, BRI Syariah, Bank Aceh Syariah. Penyebaran brosur dimaksudkan sebagai media diseminasi kepada peserta yang berasal dari masyarakat Gampong Keude Kecamatan Peudawa, Aceh Timur. Brosur-brosur ataupun leaflet terkait dengan beberapa produk-produk perbankan syari'ah dibagikan kepada seluruh peserta diseminasi.

\section{Demonstrasi, Pelatihan, dan Bimbingan}

Disamping pemberian materi tentang akad dan produk bank syariah, dalam pelatihan ini juga memperagakan dan mempercontohkan cara mekanisme perhitungan bagi hasil yang meliputi metode perhitungan bagi hasil, tahapan perhitungan bagi hasil, faktor penentu bagi hasil dan profit margin perbankan syariah.

\section{Diskusi dan Konsultasi}

Pada saat diseminasi/pelatihan dan bimbingan disertai dengan diskusi dan konsultasi untuk lebih memantapkan kegiatan pengabdian kepada masyarakat yang dilaksanakan.

\section{Evaluasi Program}

Evaluasi pada akhir kegiatan ini dilakukan untuk mengukur keberhasilan dari seluruh program pelatihan. Adapun indikator keberhasilan dari kegiatan ni ditetapkan $80 \%$ peserta dalam kegaitan pelatihan ini dapat memahami konsep dan sistim dari perbankan syariah.

\section{Peserta}

Kegiatan diseminasi akad dan produk perbankan syariah yang dilakukan dalam rangkaian kegiatan Pengabdian kepada Masyarakat ini diikuti oleh perwakilan masyarakat Gampong Keude Kecamatan Peudawa, Aceh Timur dan mahasiswa peserta kegiatan kuliah pengabdian masyarakat dari IAIN Lhokseumawe.

\section{Proses Kegiatan}

Proses kegiatan dilaksanakan dalam 1 (satu) kali pertemuan yang dimulai jam 08.00-17.00 WIB adalah sebagai berikut:

Diseminasi akad dan produk bank syariah sebagai bentuk pengenalan kepada masyarakat dari masyarakat 
Suryani. Diseminasi Akad Dan Produk Bank Syariah Pada Masyarakat Gampong...

Gampong Keude Kecamatan Peudawa, Aceh Timur dilaksanakan dengan metode ceramah dan diskusi. Diskusi dilakukan secara terbuka. Adapun materi yang akan diberikan sebagai berikut:

\begin{tabular}{|c|c|c|}
\hline Waktu & Materi & Fasilitator \\
\hline \multicolumn{3}{|c|}{ Selasa, 10 Maret 2020} \\
\hline $\begin{array}{l}07.30- \\
08.00\end{array}$ & Registrasi & $\begin{array}{l}\text { Panitia dari } \\
\text { Mahasiswa }\end{array}$ \\
\hline $\begin{array}{l}08.00- \\
08.30\end{array}$ & Pembukaan & $\begin{array}{l}\text { - Kepala } \\
\text { Desa/Keuchik } \\
\text { Gampong } \\
\text {-Ketua } \\
\text { pelaksana } \\
\text { kegiatan } \\
\text { "Diseminasi } \\
\text { Akad dan } \\
\text { Produk Bank } \\
\text { Syariah” } \\
\end{array}$ \\
\hline $\begin{array}{l}08.30- \\
11.30\end{array}$ & 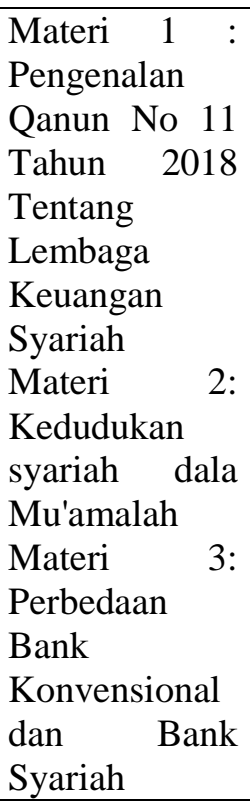 & $\begin{array}{l}\text { Narasumber : } \\
\text { Dr. Suryani, } \\
\text { M.Si. }\end{array}$ \\
\hline $\begin{array}{l}13.00- \\
17.00\end{array}$ & $\begin{array}{l}\text { Materi 4: } \\
\text { Produk } \\
\text { Penghimpunan } \\
\text { dana (funding) } \\
\text { Materi 5: } \\
\text { Produk } \\
\text { Penyaluran } \\
\text { dana } \\
\text { (Financing) } \\
\text { Materi 6: } \\
\text { Produk Jasa }\end{array}$ & $\begin{array}{l}\text { Narasumber : } \\
\text { Dr. Suryani, } \\
\text { M.Si. }\end{array}$ \\
\hline $\begin{array}{l}17.00- \\
17.35\end{array}$ & Penutupan & \\
\hline
\end{tabular}

\section{HASIL DAN PEMBAHASAN}

\section{Tahapan Pelatihan}

\section{Tahap Perencanaan Kegiatan}

Tim pelaksana pada awal kegiatan mengundang para masyarakat, tokoh-tokoh masyarakat. Selanjutnya tim pelaksana menentukan sasaran diseminasi ini adalah para masyarakat dan tokoh-tokoh masyarakat di Desa Gampong Keude Kecamatan Peudawa Kabupaten Aceh Timur.

Diseminasi akad produk banka syariah meliputi materi-materi diantaranya yaitu:

1) Mengenai pengenalan Qanun No. 11 Tahun 2018 tentang Lembaga Keuangan Syariah.

2) Kedudukan syariah dalam mua'malah.

3) Perbedaan bank konvensional dan bank syariah.

4) Produk Penghimpunan Dana (Funding),

5) Produk Penyaluran Dana (Financing),

6) Produk dan Jasa Bank Syariah.

\section{Tahap Pelaksanaan Kegiatan}

Materi diseminasi disampaikan melalui ceramah di aula Masjid Gampong Aceh, dan konsumsi disiapkan oleh tim/mahasiswa kuliah pengabdian masyarakat dilanjutkan dengan tanya jawab. Pelaksanaan diseminasi dilakukan sebanyak 1 (satu) kali kegiatan.

Penyampaian/pemberian teori pada pelaksanaan kegiatan ini dilakukan oleh Dosen Fakultas Ekonomi dan Bisnis Islam yang memang memiliki kapasitas dan kapabilitas pengetahuan di bidang perbankan syariah. Model pelaksanaan kegiatan diseminasi mulai dilakukan dengan membagikan brosurbrosur dan leaflet produk bank syariah, penyampaian materi, diskusi dan 
simulasi/latihan terkait dengan beberapa contoh kasus metode perhitungan bagi hasil, tahapan perhitungan bagi hasil, faktor penentu bagi hasil. Tujuan dari kegiatan simulasi ini diharapkan peserta pelatihan dapat mengimplementasikan hasil diseminasi tersebut dalam kehidupan sehari-hari.

\section{Tahap Akhir Kegiatan dan Evaluasi}

Evaluasi pada akhir kegiatan ini dilakukan untuk mengukur keberhasilan dari seluruh program pelatihan. Adapun indikator keberhasilan dari kegiatan ini ditetapkan $80 \%$ peserta dalam kegiatan pelatihan ini dapat memahami konsep dan sistem dari perbankan syariah.

Hasil yang dicapai dari pemberian materi pelatihan ini adalah para masyarakat umum, para tokoh masyarakat mendapatkan pemahaman serta keterampilan tentang akad dan produk perbankan syariah yang diharapkan dengan bekal pengetahuan tersebut dapat diaplikasikan dalam kehidupan berekonomi secara Islami.

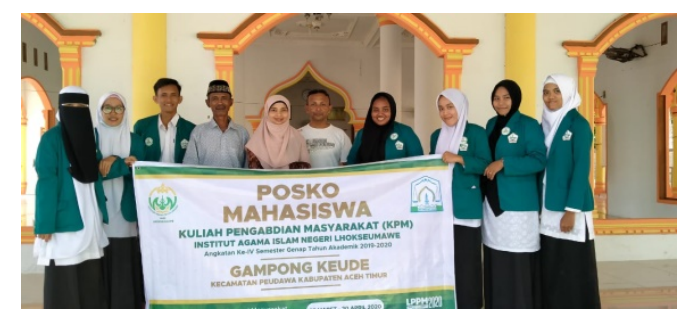

Gambar 1. Survey Kegiatan Diseminasi Akad dan Produk Bank Syariah pada Masyarakat Gampong Keude Peudawa Aceh Timur

Secara umum kegiatan pengabdian kepada masyarakat dalam hal ini program diseminasi akad dan produk direspon baik oleh masyarakat peserta pelatihan. Setiap peserta mengikuti dengan seksama penjelasan tahapan pelatihan. Peserta yang mengikuti melebihi dari target undangan peserta yang telah ditetapkan.

Awal kegiatan dilakukan survey pendahuluan dan wawancara dengan masyarakat sasaran pemberian pelatihan. Berdasarkan hasil survey tersebut diketahui bahwa sebagian besar masyarakat mengetahui akan produkproduk perbankan syariah maupun beberapa akad bank syariah. Akan tetapi mereka belum mengetahui secara lengkap dan mendalam bagaimana model-model transaksi derivatif dan keuntungan yang dapat diperoleh dari akad maupun produk perbankan syariah di lembaga keuangan syari'ah yang ada (Mutaqin, 2015). Sehingga, dapat disimpulkan bahwa meskipun masayrakat mengetahui keberadaan akad dan produk syariah akan tetapi dalam kehidupan sehari-hari lebih mengutamakan sistem yang sifatnya konvensional yang memang sudah diketahui dan lebih familiar dikalangan masyarakat.

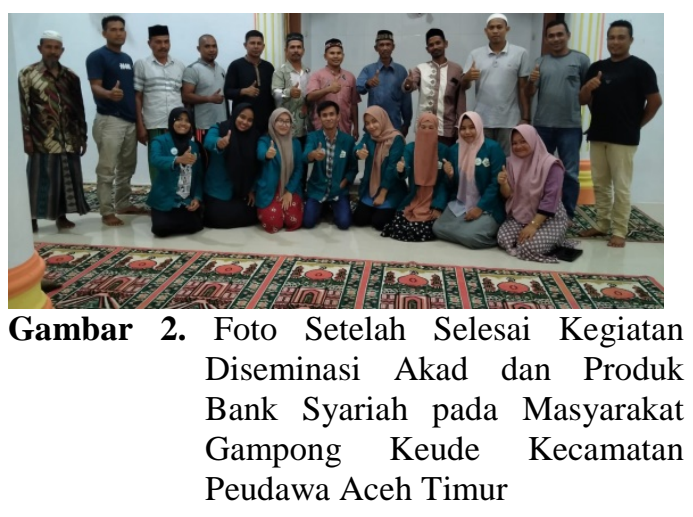

Kegiatan akad dan produk perbankan syariah dilaksanakan dalam bentuk pelatihan, diawali dengan ceramah dan diskusi secara teoritis, dilanjutkan dengan praktik serta bimbingan dan konsultasi. Dengan tahapan-tahapan kegiatan tersebut, peserta diharapkan memiliki pengetahuan dan wawasan lebih dalam terkait dengan akad dan produk yang ada diperbankan syariah.

\section{SIMPULAN}


Pelaksanaan kegiatan pengabdian pada masyarakat dengan tema "Diseminasi Akad dan Produk Bank Syariah Masyarakat Gampong Keude Kecamatan Peudawa, Aceh Timur. Masyarakat Aceh pada umunya beragama Islam dan sangat fanatik dalam mengamalkan ajaran agama, harusnya hal ini bisa memotivasi masyarakat Muslim di Aceh untuk menjadi nasabah bank syariah. Tingkat efektifitas keterlibatan masyarakat Muslim dalam bank syariah tergantung pada sikap dan pola pikir masyarakat Muslim itu sendiri. Meskipun memang upaya-upaya yang lebih terstruktur dan berkesinambungan harus terus dilakukan dan diimplementasikan agar mampu mengubah sikap dan pola pikir masyarakat di masa mendatang.

$\begin{array}{ccr}\text { Secara } & \text { umum } & \text { kegiatan } \\ \text { pengabdian } & \text { masyarakat } & \text { dengan }\end{array}$ mengadakan diseminasi akad dan produk bank syariah telah berhasil dengan tercapainya luaran yang diharapkan yang berupa prospek nasabah potensial dan minat untuk menabung di bank syariah dibuat oleh perserta pelatihan. Hasil evaluasi dari kegiatan sosialisasai menunjukkan bahwa masyarakat perserta diseminasi setidaknya telah memahami sekilas bagaimana cara berinvestasi dan menabung di bank syariah.

\section{UCAPAN TERIMA KASIH}

Terimakasih kami ucapkan kepada, 1) Lembaga Penelitian dan Pengabdian Kepada Masyarakat IAIN Lhokseumawe Bapak Dr. Syahrizal, MA, khususnya ketua panitia pelaksana kegiatan Kuliah Pengabdian Masyarakat Bapak Sofyan Arianto, M.Pd, Camat Pereulak Aceh Timur, 2) Kepala Desa yaitu Bapak Bahtiar, BA dan Paklah sebagai Kepala Dusun, serta seluruh masyarakat Gampong Keude
Kecamatan Peudawa Kabupaten Aceh Timur 3) mahasiswa IAIN Lhokseumawe sebagai peserta Kuliah Pengabdian Masyarakat kelompok 53 desa Gampong Keude Kecamatan Peudawa Aceh Timur yaitu M. Fadhil Fakultas Ushuluddin Adab dan Dakwah Jurusan Komunikasi Penyiaran Islam, Ira Fauziah Fakultas Ilmu Tarbiyah dan Ilmu Keguruan Jurusan Pendidikan Guru dan Madrasah Ibtidaiyah, Intan Sari Fakultas Syariah Jurusan Hukum Tata Negara, Chintia Utary Fakultas Ekonomi dan Bisnis Islam Jurusan Ekonomi Syariah, Cut Intan Farhani Fakultas Tarbiyah dan Ilmu Keguruan Fakultas Tadris Bahasa Inggris, Rauzatul Jannah Fakultas Ekonomi dan Bisnis Islam Jurusan Ekonomi Syariah. Husnul Khatimah Fakultas Tarbiyah dan Ilmu Keguruan Jurusan Pendidikan Bahasa Arab sehingga kegiatan ini dapat dilaksanakan, serta reviewer dan editor Jurnal Martabe Jurnal Pengabdian pada Masyarakat, sehingga saya dapat mempublikasi topik ini.

\section{DAFTAR PUSTAKA}

Al Arif, M. Nur Rianto. 2012. Lembaga Keuangan Syariah Suatu Kajian Teoritis Praktis. Bandung: Pustaka Setia.

AlGaoud, Lativa M. 2001. Perbankan Syariah: Prinsip, Praktek, Prospek. Jakarta: Serambi.

Antonio, M. Syafi'i. 2000. Pengenalan Bank Syariah.Jakarta: BI dan Tazkia Institute.

Antonio, M. 2001. Bank Syariah Dari Teori Ke Praktik. Jakarta: Gema Insani Press dan Tazkia Cendekia.

Arifin, Zainul. 2000. Memahami Bank Syari'ah: Lingkup, Peluang, Tantangan dan Prospek. Jakarta: Alvabet. 
Ascarya. 2007. Akad \& Produk Bank Syariah. Jakarta: PT RajaGrafindo Persada.

Hidayah, A. N., \& Kartini, I. A. (2017). Peranan Bank Syariah dalam Sosialisasi dan Edukasi Masyarakat Tentang Kemanfaatan Produk dan Jasa Perbankan Syariah. Kosmik Hukum, 16(1), 74-86.

Idawati, Satriawan. D, \& Afandi, M. (2020). Sosialisasi Produk Lembaga Keuangan Syariah Pada Masyarakat Desa Batu Tegi Kecamatan Air Naningan Kabupaten Tanggamus Propinsi Lampung. Al-Mu'awanah: Jurnal Pengabdian Kepada Masyarakat, $1(1)$, http://www.ejournal.radenintan.ac .id/index.php/ajpm/article/view/61 78/3482.

Karim, Adiwarman A. 2004. Bank Islam Analisis Fiqh dan Keuangan. Edisi Dua. Jakarta: PT RajaGrafindo Persada.

Karnaen A. Perwataatmadja dan M. Syafi'i Antonio. 1992. Apa dan Bagiamana Bank Syari'ah. Yogyakarta: Dana Bhakti Wakaf.

Machmud, Amir dan Rukmana. 2010. Bank Syariah: Teori, Kebijakan dan Studi Empiris di Indonesia. Jakarta: Erlangga.

Maleha Yanti, N \& Choiriyah. (2018). Sosialisasi Pengenalan Lembaga Keuangan Konvensional dan Syariah di SMA Adabiyah Palembang, Jurnal Abdimas Mandiri 2(1), 11-18. http://ejournal.uigm.ac.id/index.p hp/PGM/article/view/448

Maleha Yanti, N \& Fadillah. (2019). Sosialisasi Pemasaran dan Komunikasi Terhadap Minat Nasabah untuk Menabung di BMT, Jurnal Abdimas Mandiri 3(2), 109-114. http://journal.umsurabaya.ac.id/index.php/HMN/ar ticle/view/4542/2676

Masnita, Y, Tiyowati H, \& Khomsiyah. (2020). Pemberdayaan Lembaga Keuangan Syariah dalam Meningkatkan Peran Inklusi Keuangan. JUARA: Jurnal Wahana Abdimas Sejahtera.1(1), 26-37.

https://www.trijurnal.lemlit.trisakt i.ac.id/juara/article/view/5911/482 9

Santoso, I. (2018). Sosialisasi dan Pelatihan Implementasi AkadAkad dan Produk Perbankan Syariah. Jurnal Pengabdian Masyarakat, 3 (2), 151-158. http://ppm.ejournal.id/index.php/p engabdian/article/view/66

Setiyowati, A \& Lailatul L. (2020). Literasi Keuangan Syariah Melalui Media Edukatif untuk Anak Usia Sekolah Dasar di SD Muhammadiyah Surabaya. Jurnal Humanism, 1(1), 13-22. http://journal.umsurabaya.ac.id/index.php/HMN/ar ticle/view/4542/2676 